Vol. 44, N. 3 : pp. 257 - 261, September, 2001

ISSN 1516-8913 Printed in Brazil

\title{
Incidence of Group A Rotavirus in Urban and Rural Areas of the City of Londrina-Brazil, from 1995 to 1997
}

\author{
Ângelo Cesar Meneghetti, Andrea Maria Bolognini, Flávio Lauretti, Rosa Elisa Carvalho \\ Linhares, Norma Santos ${ }^{1}$ and Carlos Mitihiko Nozawa* \\ Departamento de Microbiologia. CCB. Universidade Estadual de Londrina. CEP 86.061-970. Londrina - PR, \\ Brazil; 1- Departamento de Virologia. Instituto de Microbiologia Prof. Paulo de Góes. Universidade Federal do \\ Rio de Janeiro. CEP 21.941-590. Rio de Janeiro - RJ, Brazil
}

\begin{abstract}
Rotaviruses are common pathogens and the causal agents of acute diarrhea among children and young animals. The involvement of rotavirus in human diarrheal disease among population of urban and rural areas of the city of Londrina, Parana was evaluated. Nine hundred and five fecal specimens from persons with diarrhea were studied, being 686 and 219 from urban and rural areas, respectively. Thirty-eight samples (4,2\%) were positive for rotavirus by polyacrylamide gel electrophoresis of viral RNA and latex agglutination test of which 36 were from urban and two from rural areas. Out of the positive specimens, 17 strains were further characterized by RT-PCR typing assay, resulting in 16 strains of G1 genotype while one sample was found to be a mixture of G1 and G3 genotypes.
\end{abstract}

Key words: Rotavirus, Diarrhea, PAGE, LA, PCR

\section{INTRODUCTION}

Rotaviruses are the major cause of acute diarrhea of viral etiology among humans and animals (Kapikian, 1996). They belong to the Reoviridae family and possess a genome of 11 double-stranded RNA segments, which are enclosed by a core and a double-capsid shell (Estes, 1996). Based on their antigenic characteristics, rotaviruses are classified into seven groups (A - G). Group A rotaviruses are yet classified into $G$ and $P$ types, respectively, on the basis of the VP7 and VP4 proteins present on the outer shell of the virus (Hoshino \& Kapikian, 1996). Natural interspecies transmission of rotavirus among human and animal appears to be a possible event, suggesting a putative anthropozoonotic characteristic of the infection (Isegawa et al., 1992; Li et al.,1993;1993a; Nakagomi et al., 1993). The significance of such events on rotavirus epidemiology and pathogenicity is still unknown. However, the knowledge and understanding of the mechanisms involved in those interactions are critical for the development of an efficient strategy for preventing rotavirus infection and disease. Previous studies have shown evidences for natural human-porcine genetic reassortment of rotavirus strains in the State of Parana (Alfieri et al., 1996; Santos et al., 1999). In order to get insight on this matter, we developed the present study. Our purpose was to verify the incidence of rotavirus disease among humans in urban and rural areas of the city of Londrina, in an attempt to trace the occurrence of interspecies transmission, taking into account that rural population live in close contact with domesticated animals.

\footnotetext{
* Author for correspondence
} 


\section{MATERIALS AND METHODS}

Nine hundred and five fecal samples were collected from individuals with diarrhea, living in urban and rural areas of the city of Londrina, State of Parana, from May 1995 to March 1997. Four hundred and thirty-one samples were from children under five years of age, being 72 and 359 samples from the rural and urban areas, respectively. Four hundred and seventy-four samples were from individuals between 5 and 68 years of age, being 147 and 327 from rural and urban areas, respectively. The samples were initially analyzed by polyacrylamide gel electrophoresis (PAGE) (Herring et al., 1982) and latex agglutination (LA) test (Slidex Rota kit II, BioMérieux, France) for the presence of rotavirus. Seventeen rotavirus positive samples available were further characterized by a reverse transcriptase-polymerase chain reaction (RT-PCR) based typing assay for identification of $G$ types (Gouvea et al., 1990; Gouvea et al., 1994).

\section{RESULTS}

Thirty-eight samples $(4.2 \%)$ were positive for the presence of rotavirus either by PAGE, LA, or both (Fig.1). According to PAGE, all strains presented group A electropherotype, being 37 with long pattern profile and one with short pattern. Thirtysix samples were from urban area individuals $(5.2 \%)$, whereas two samples were from persons living in rural area $(0.9 \%)$. All the positive samples from the urban area belonged to children under five years of age, except one from a 29year-old woman. The two positive samples of the rural area were also from children under five years of age. Out of the positive samples, 17 were further characterized by RT-PCR typing assay demonstrating that 16 were G1 genotype (Fig.2) while one sample was found to be a mixture of G1 and G3 genotypes.

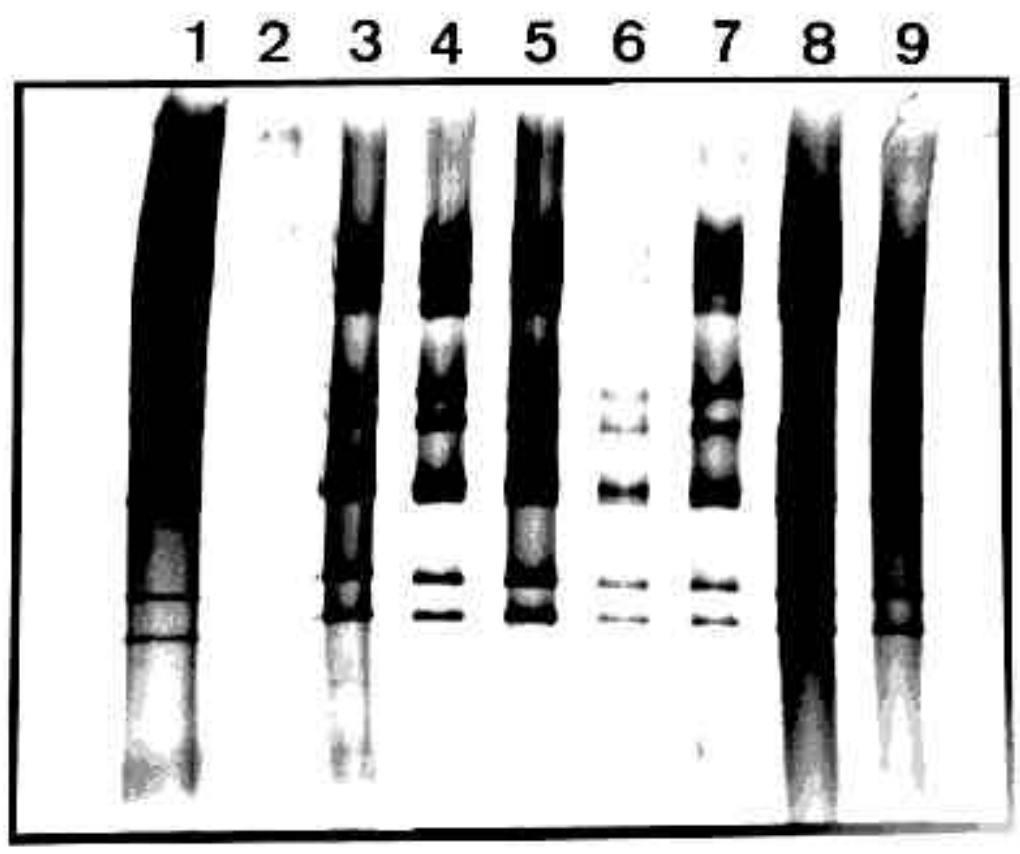

Figure 1 - Polyacrylamide gel electrophoresis of rotavirus strains RNA detected in human feces. Viral RNA was prepared with guanidine isothiocyanate and extracted with hydroxyapatite and cetyltrimethylammonium bromide (Santos \& Gouvea, 1994). Lane 1, internal standard human rotavirus NS84; Lane 2, nihil; Lanes 3-9, strains of rotavirus detected in the following fecal specimens pat1, pat10, pat19, psc54, psc475, psc506 and psc521, respectively. 


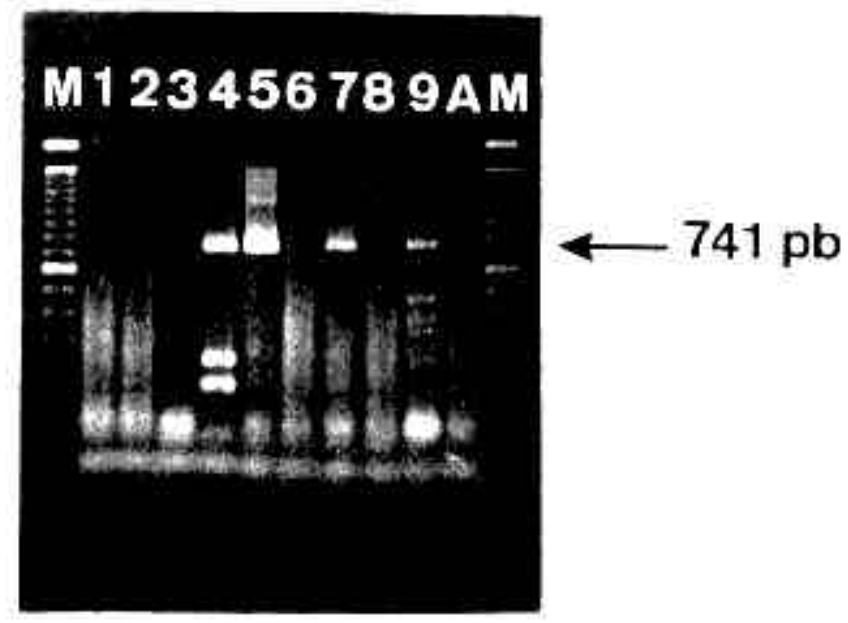

Figure 2 - Reverse Transcriptase-Polymerase Chain Reaction for G typing (VP7) of human rotavirus strains detected in feces (Gouvea et al., 1990). Lanes M, 100 pb ladder MW marker; Lanes 1-3, 6, 8 and A, nihil; Lanes 4, 5, 7 and 9 represent amplifications of strains detected in fecal specimens pat6, pat11, hu15 and pat16, respectively. Arrow indicates de amplification product of $741 \mathrm{pb}$ corresponding to the genotype G1.

\section{DISCUSSION}

The findings revealed a very low incidence of rotavirus in human population in the studied area (4.2\%), compared to a rather high incidence in other areas of Brazil, bearing in mind that rural population and adult individuals were included. Previous studies in other cities in this country demonstrated an incidence of rotavirus infection varying from $11 \%$ to $21 \%$ (Timenetsky et al., 1993; Pereira et al., 1994; Santos et al., 1999a; Alverca et al., 1999). Those studies were performed among children under two years of age of the urban zone. The incidence of rotavirus among rural population in Londrina was only $0.9 \%$. To date there is no data available on human rotavirus infection in the Brazilian rural population; however, data from rural areas in Egypt, Guatemala and Bangladesh demonstrated higher rates of 3,14 and 50\%, respectively, but again, children under two years of age were the target population (Wyatt et al., 1979; Black et al., 1980; Zaki et al., 1986). One could expect a higher incidence of the disease in rural area of the city of Londrina $(0.9 \%)$ in comparison to that of urban area $(5.2 \%)$. Although rural areas usually do not present sanitation coverage as urban areas it should not interfere with the occurrence of rotavirus diarrhea. It was reported that improvements of water, food, and sanitation are unlikely to reduce the disease incidence
(Parashar et al., 1998). The low incidence of rotavirus in rural area of Londrina is, therefore, consistent with low incidence in the city overall. The RT-PCR assay revealed a predominance of serotype or genotype G1, as sixteen out of seventeen strains presented only this serotype. One strain demonstrated a mixture of serotypes $\mathrm{G} 1$ and G3. G1 and G3 are the major rotavirus serotypes infecting humans around the world (Hoshino \& Kapikian, 1996). It was also previously demonstrated to be common serotypes among the human population in Londrina (Leite et al., 1996). Rotavirus serotype G5 is frequently detected among porcine and equine (Hoshino \& Kapikian, 1996). Its detection among humans was first described in Brazil in 1994 (Gouvea et al., 1994a) and, since then, it has been demonstrated to be a common human pathogen in that country (Alfieri et al., 1996; Leite et al., 1996; Santos et al., 1998; Santos et al., 1999a). At the beginning of the current study we speculated that if we could find human rotavirus infection caused by serotype G5 in the rural population, it would suggest the interspecies transmission hypothesis, as this serotype was found in porcine in the same State (Santos et al., 1999). However we did not detect serotype G5 in the present work, even though it was detected in the human population of Londrina before (Alfieri et al., 1996; Leite et al., 1996). It could be possible that we did not find G5 strains because of the limited number of strains 
typed. On the other hand, it was recently demonstrated that serotype G1 circulated among porcine in the southwest region of the State as early as 1991 (Santos et al., 1999). These findings created a new possibility of interspecies transmission according to our current data that demonstrated G1 serotype as

the most prevalent in the city of Londrina.

Unfortunately, the rural area studied in the current work where human strains G1 were detected did not correspond to that where porcine G1 strains were demonstrated (Santos et al., 1999). Otherwise, it would be a suggestive datum of interspecies transmission from porcine to human and/or vice-versa. In conclusion, a long-term prospective study of human and animal rotaviruses interaction in rural area ought to be pursued in order to better understanding the putative anthropozoonotic nature of rotavirus infection.

\section{ACKNOWLEDGEMENTS}

This work was partially supported by CAPES, CNPq, CPG/UEL, PROUNI/UEL, FINEP, FAPERJ and FUJB/UFRJ. It is part of M.Sc. manuscript of ACM who was in receipt of $\mathrm{CNPq}$ scholarship.

\section{RESUMO}

Os rotavírus são patógenos comuns e causam diarréia aguda em crianças e animais jovens. Neste trabalho avaliamos a participação do vírus na diarréia de populações humanas das áreas urbana e rural da cidade de Londrina, Paraná. Foram analisadas 905 amostras fecais de indivíduos com diarréia aguda, sendo 686 e 219 amostras das zonas urbana e rural, respectivamente. Trinta e oito amostras (4,2\%) foram consideradas positivas pelas técnicas de eletroforese em gel de poliacrilamida do RNA viral e aglutinação passiva de látex, das quais 36 da área urbana e dois da área rural. Das amostras positivas, 17 foram genotipadas por RT-PCR tendo sido caracterizadas 16 cepas G1 e uma considerada mistura dos genótipos G1 e G3.

\section{REFERENCES}

Alfieri, A.; Leite, J. P. G.; Nakagomi, O.; Kaga, E.; Woods, P. A.; Glass, R. I. and Gentsch, J. R. (1996), Characterization of human rotavirus genotype $\mathrm{P}[8] \mathrm{G} 5$ from Brazil by probe-hybridization and sequence. Arch. Virol., 141, 2353-2364

Alverca, V. O.; Gomes, T. S.; Silva, M. L. R.; Domingues, A. L. S. and Santos, N. (1999), Incidência de gastrenterite infantil de etiologia viral em Juiz de Fora, Minas Gerais, no período de janeiro a dezembro de 1998. J. Bras. Patol., in press

Black, R. E.; Merson, M. H.; Rahman, A. S. M. M.; Yunus, M.; Alim, A. R. M. A.; Huq, I.; Yolken, R. H. and Curlin, G. T. (1980), A two-year study of bacterial, viral, and parasitic agents associated with diarrhea in rural Bangladesh. J. Infect. Dis., 142, 660664

Estes, M. K. (1996), Rotaviruses and their replication. In-Virology, eds. B. N. Fields; D. M. Knipe; P. M. Howley et al., Lippincott-Raven, Philadelphia, 16251655

Gouvea, V.; Glass, R. I.; Woods, P.; Taniguchi, K.; Clark, H. F.; Forrester, B. and Fang, Z.-Y. (1990), Polymerase chain reaction amplification and typing of rotavirus nucleic acid from stool specimens. $J$. Clin. Microbiol., 28, 276-282

Gouvea, V.; de Castro, L.; Timenetsky, M. C.; Greenberg, H. B. and Santos, N. (1994), Rotavirus serotype G5 associated with diarrhea in Brazilian children. J. Clin. Microbiol., 32, 1408-1409

Gouvea, V.; Santos, N.; and Timenetsky, M. T. (1994a), Identification of bovine and porcine rotaviruses $\mathrm{G}$ types by PCR. J. Clin. Microbiol., 32, 1338-1340

Herring, A. J.; Inglis, N. F.; Ojhe, C. K.; Snodgrass, D. R. and Menzies, J. D. (1982), Rapid diagnosis of rotavirus infection by direct detection of a viral nucleic acid in silver-stained polyacrylamide gels. $J$. Clin. Microbiol., 16, 473-477

Hoshino, Y. and Kapikian, A. Z. (1996), Classification of rotavirus VP4 and VP7 serotypes. Arch. Virol., [Suppl] 12, 99-111

Isegawa, Y.; Nakagomi, O.; Nakagomi, T. and Ueda, S. (1992), A VP4 sequence highly conserved in human rotavirus strain AU-1 and feline rotavirus strain FRV1. J. Gen. Virol., 73, 1939-1946

Kapikian, A. Z. (1996), Overview of viral gastroenteritis. Arch. Virol., [Suppl] 12, 7-9

Leite, J. P. G.; Alfiere, A.; Woods, P. A.; Glass, R. I. and Gentsch, J. R. (1996), Rotavirus G and P types circulating in Brazil, characterization by RT-PCR, probe-hybridization, and sequence analysis. Arch. Virol., 141, 2365-2374

Li, B.; Clark, H. F. and Gouvea, V. (1993), Nucleotide sequence of the VP4-encoding gene of an unusual human rotavirus (HCR3). Virology, 196, 825-830 
Li, B.; Clark, H. F. and Gouvea, V. (1993a), Similarity of the VP7 protein of human rotavirus HCR3 to that of canine and feline rotavirus. J. Gen. Virol., 75, 215219

Nakagomi, O. and Nakagomi, T. (1993), Interspecies transmission of rotavirus studied from the perspective of genogroup. Microbiol. Immunol., 37, 337-348

Parashar, U. D.; Bresee, J. S.; Gentsch, J. R. and Glass, R. I. (1998), Rotavirus. Emerg. Infect. Dis., 4, 561570

Pereira, H. G.; Linhares, A. C.; Candeias, J. A. N. and Glass, R. I. (1994), National laboratory surveillance of viral agents of gastroenteritis in Brazil. Bol. Of. Sanit. Panam., 116, 27-36

Santos, N. and Gouvea, V. (1994), Improved method for purification of viral RNA from fecal specimens for rotavirus detection. J.Virol.Methods, 46, 11-21

Santos, N.; Lima, R. C. C.; Pereira, C. F. A. and Gouvea, V. (1998), Detection of rotavirus G8 and G10 among Brazilian children with diarrhea. J. Clin. Microbiol., 36, 2727-2729

Santos, N.; Lima, R. C. C.; Nozawa, C. M.; Linhares, R. E. C. and Gouvea, V. (1999), Detection of porcine type G9 and a mixture of types G1 and G5 associated with Wa-like VP4 specificity, evidence for natural human-porcine genetic reassortment. J. Clin. Microbiol., 37, 2734-2736
Santos, N.; Lima, R. C. C.; Pereira, C. F. A. and Gouvea, V. (1999a), Detecção de rotavírus atípicos em crianças com diarréia no Rio de Janeiro. News Lab., 32, 78-86

Timenetsky, M. C. S. T.; Kiselius, J. J.; Grisi, S. J. F. E.; Escobar, A. M.; Ueda, M. and Tanaka, H. (1993), Rotavírus, adenovírus, astrovírus, calicivírus e "small round virus particle" em fezes de crianças com e sem diarréia aguda, no período de 1987 a 1988, na Grande São Paulo. Rev. Inst. Med. Trop. São Paulo, 35, 275280

Wyatt, R. G.; Yolken, R. H.; Urrutia, J. J.; Mata, L.; Greenberg, H. B.; Chanock, R. M. and Kapikian, A. Z. (1979), Diarrhea associated with rotavirus in rural Guatemala, a longitudinal study of 24 infants and young children. Am. J. Trop. Med. Hyg., 28, 325-328

Zaki, A. M.; DuPont, H. L.; El Alamy, M. A.; Arafat, R. R.; Amin, K.; Awad, M. M.; Bassiouni, L.; Imam, I. Z.; El Malih, G. S.; El Marsafie, A.; Mohieldin, M. S.; Naguib, T.; Rakha, M. A.; Sidaros, M.; Wasef, N.; Right, C.E. and Wyatt, R.G. (1986), The detection of enteropathogens in acute diarrhea in a family population in rural Egypt. Am. J. Trop. Med. Hyg., 35, 1013-1022 